\title{
Medzinárodná konferencia „Sasko-magdeburské právo ako kultúrny spojovací medzičlánok medzi právnymi poriadkami východnej a strednej Európy. Stav a perspektívy budúceho vývoja“‘, Saská akadémia vied v Lipsku, 14.-15. novembra 2018
}

Ked' anhaltský rytier Eike von Repgow spísal v rokoch 1220 až 1235 svoj skromný súkromný počin zbierky saského práva, známy pod v súdobej stredovekej spisbe obvyklým názvom Sachsenspiegel - Saské zrkadlo, netušil, že vytvorí dielo svetového významu. Táto zbierka dovtedy ústne tradovaného lénného a krajinského saského obyčajového práva sa stala, ako je historickému a právnohistorickému odbornému publiku už dávno dobre známe, synonymom pre exportované nemecké právo do oblastí najmä nenemeckých, prevažne osídlených slovanským obyvatel'stvom a v tom čase už intenzívne-extenzívne kolonizovaných tiež nemeckými host’ami. O jeho autorite a historickom dedičstve sa popísalo a poreferovalo na rôznych fórach už mnoho a napokon aj predmetná konferencia, konaná v polovici novembra roka 2018 na Saskej akadémii vied v Lipsku, toho bola nesporným príkladom. Predsa však uvedená konferencia má viacero pozitívne vnímaných konotácií.

Konferenciu organizovala Saská akadémia vied v Lipsku ako materská vedecká inštitúcia, ktorá zastrešuje už viac ako 15 rokov trvajúci a sústavne pokračujúci medzinárodný projekt právnohistorického a lingvistického výskumu $\mathrm{k}$ významu a transferu sasko-magdeburského práva a ním vytvoreného rozsiahleho právneho okruhu dcérskych fílií a lokalít, ktoré sa ním v stredoveku a novoveku nechali inšpirovat', či rovno sa ním aj spravovali. Projekt zastrešuje uvedená inštitúcia pod vedením prof. H. Lücka ako hlavného koordinátora. Hlavnými spolupracovníkmi na projekte sú toho času Dr. Wieland Carls a Dr. Katalin Göncziová (obaja pôsobiaci na uvedenej organizátorskej inštitúcii), ktorí reprezentujú aj dve hlavné pracoviská projektu: Lipsko a Magdeburg.

V úvodných príhovoroch prof. H. Lücka, Dr. W. Huschnera a saského krajinského ministra kultúry R. Robru v prvý deň konferencie (14. novembra 2018) sa vyzdvihol doterajší vedecký diskurz k vyššie zmienenej stredovekej právnej zbierke, prízvukovalo sa, že dejiny musia mat' svoju identitu, a vyjadrili tak presvedčenie ukotvenia onej zbierky pre budúcnost' Európy, ktorá sa musí zastat' a kriticky skúmat' jedinečné historické nositele duchovných pilierov Európy (krest’anský univerzalizmus vedno s v renesancii nanovo artikulovaným individualizmom), medzi ktoré radia všetci unisono túto právnu zbierku.

V predpoludňajšom bloku nasledovali stručné referáty hlavných účastníkov daného projektu a to prof. H. Lücka, Dr. W. Carlsa, Dr. K. Göncziovej a Dr. M. Lazarovej. V projekte sa doteraz publikovali nasledovné publikácie: vedecký zborník z r. 2008 $\mathrm{k}$ téme Právny a jazykový transfer do strednej a východnej Európy, dve monografie: 
Sasko-magdeburské právo v Pol’sku (autori: W. Carls, K. Gönczi, I. Bily) a Sasko-magdeburské právo v Mad’arsku a Rumunsku (autorka: K. Gönczi) a naposledy zborník z vedeckej konferencie v Segedíne z r. 2015 s názvom Výskum Švábskeho zrkadla v dunajskom priestore. Referujúci pripomenuli viaceré historické charakteristiky k danému výskumu: viacetapovitost' právneho transferu, jeho geografické smery a míl'niky a rozmanitost' a variabilitu jednotlivých jazykových redakcií danej zbierky. V príspevku Právny jazyk ako systematický predmet poznania a smery jeho digitalizovaného výskumu litovskej lingvistiky M. Lazarovej zazneli viaceré podnetné príklady, argumentujúc predovšetkým stredovekými prameňmi: napr. českou zbierkou Pražských práv a slovenskou Žilinskou mestskou knihou. Prof. H. Lück sa zaoberal vel'mi dôležitými otázkami a kritickými glosami k uvedenému projektu a z jeho referátu možno akcentovat' nasledovné zámery a otázniky budúceho výskumu: problémy interdisciplinárnych, medzinárodných výskumných tímov a bádatel'ov a ich vzájomnej spolupráce (efektivita vedeckého managementu a nevyhnutná potreba pevnej siete spolupracujúcich pracovísk), kritické zhodnotenie impozantnej vedeckej spisby k problematike sasko-magdeburského práva (čo súvisí aj so spracovaním dejín daného výskumu), problém pojmovej definície magdeburského práva transponovaného a transformovaného v prijímatel'ských (dcérskych) krajinách, lokalitách, etnikách a societach. Jeho kolega W. Carls potom zdôraznil dnes už nevyhnutnú elektronizáciu celého projektu alebo jeho čiastkových výstupov, (pre)sumovania metadát a pod., náročnost' transkribcie jednotlivých redakcií, a predstavil aktuálne pripravovaný monografický počin transferu sasko-magdeburského práva v Čechách a na Slovensku (autorkou bude opätovne stabilná pracovníčka saskej akadémie a daného projektu Dr. Gönczi), na čo sa v našich, slovensko-českých právnohistorických kruhoch budeme len a len tešit' (rovnaké želanie prejavil aj v diskusii prítomný mad'arský kolega prof. B. Szabó z Pät'kostolia). Z pléna v diskusii potom zaznela zaujímavá a vel’avravná otázka: Či sasko-magdeburské právo ponúka jednotu v rôznorodosti alebo rôznost' v jednote? K. Gönczi uvedené glosovala potrebou diferenciácie jednotlivých transferov, ktoré mali rôznu hĺbku a kvalitu. Zaznela aj otázka tematizácie medzinárodnej migrácie l'udí a ich myšlienok (resp. právnych ideí).

V d’alšom bloku prvého dňa vystúpil prof. Puhle, ktorý načrtol umelecké a filozofické reflexie sasko-magdeburského práva v európskych dejinách, japonský kolega prof. Sato z univerzity $\mathrm{v}$ Koite zase pre zmenu v koreferáte ozrejmil publiku jeho záujem o európske právne dejiny a vel'mi cenný historický materiál zbierky Sachsenspiegla, pričom právny vývoj je vel'mi úzko spojený s jazykovým.

Popoludňajší blok sa niesol v znamení prezentácií najnovších výsledkov pol'ského a litovského výskumu z radov kolegov - právnych historikov: prof. D. Janickej z Toruňa (téma príspevku: Sasko-magdeburské právo v súčasnom Pol’sku. Základné smery právnohistorického výskumu), Dr. J. Karpavičiené z Vilniusu (téma: Ženy v litovských mestách sasko-magdeburského okruhu: výskum a odkrývanie európskej právnej kultúry), doc. M. Mikułu z Krakova (téma: Weichbildvulgata a pol'skí glosátori: Mikuláš Jaskier a Paweł Szczerbic - skúmanie novovekých edícií uvedenej zbierky v latinčine a pol’štine zo 16. a 18. storočia, pričom ponúkol len prvotné vedecké výsledky). Všetci traja predstavili iba čiastkové výsledky originálnych výskumov, prof. Janická okrem toho zhodnotila históriu výskumu sasko-magdeburského práva v Pol'sku za ostatných cca 200 rokov. 
Druhý deň konferencie (15. novembra) vystúpili d'alší účastníci s už aplikovaným výskumom sasko-magdeburského práva. V prvom, predpoludňajšom bloku si bolo možné tak vypočut' známe mená nemeckej historickej a lingvistickej vedy: Ch. Lübkeho (Od počiatkov mestskosti k modernému mestu vo východnej Európe), M. Hardta (Význam sasko-magdeburského práva pre sídliskové osídlenie stredovýchodnej Európy), Ch. Hannicka (Maloruský kódex z roku 1743 vo vývoji východoslovanskej právnej terminológie). Predpoludním ešte vystúpili kolegovia z Pol’ska a Ukrajiny. Doc. M. Włodarczková predstavila projekt digitalizácie pol’skej historickej terminológie v databáze s názvom Electronic Repository od Greater Poland Oaths 1386-1444. Prof. Danylenko následne tematizoval v príspevku s názvom Lokálne jazykové variácie podkarpatskoruskej historickej terminológie, ovplyvnenej moldavsko-valašskou právnou tradíciou príklad dištinktívneho jazykového výskumu miestnych slovanských dialektov v Podkarpatskej Rusi, kde sa vyskytli zo slovenského uhl'a pohl'adu aj termíny ovplyvnené slovenským jazykom.

V popoludňajšej časti potom zazneli záverečné sumarizujúce príspevky nemeckých kolegov (zväčša hlavných reprezentantov daného projektu), ktoré načrtli nové smery vývoja sasko-magdeburského práva v práve prebiehajúcich výskumoch, ako je výskum sasko-magdeburského práva v činnosti magdeburských stredovekých súdov miestnych prísažných, ktorého historickoprávna analýza stále absentuje (K. Gönczi).

Záverečné slová patrili hlavnému koordinátorovi projektu, prof. H. Lückovi, ktorý zhrnul perspektívy budúceho výskumu sasko-magdeburského práva: sasko-magdeburské právo pre neho predstavuje duchovný most medzi minulost'ou, súčasnost'ou a predstavuje iste aj akoby ,večnú“ tému budúcich výskumov. Samotná spolková krajina Sasko považuje tento výskum za sebe vlastný a vel'mi vítaný aj do budúcnosti, preto o pokračovaní tohto projektu niet pochýb. Vyzdvihol najmä dobrú spoluprácu s d’alšími výskumnými pracoviskami, ako je napr. Inštitút Max Planck für europäische Rechtgeschichte vo Frankfurte nad Mohanom. Apeloval tiež na rozširovanie medzinárodnej spolupráce s jednotlivými východoeurópskymi vedeckými inštitúciami a verbálne podporil tiež tak prepotrebný dialóg medzi právnymi historikmi a lingvistami i širšiu kooperáciu medzi nimi, resp. medzi ostatnými príbuznými spoločensko-vednými disciplínami.

V záverečnej diskusii potom zazneli vel'mi zaujímavé otázky, snád' aj budúceho výskumu (načrtnem len niektoré z nich): Čo urobilo sasko-magdeburské právo s mestskou slobodou, ked' vieme, že práve stredoveké mestské právo strednej a východnej, čiže slovanskými obyvatel'stvom predovšetkým osídlenej Európy profitovalo z jeho terminologického a právneho tezauru? Aký je zástoj sasko-magdeburského práva ako výrazného predstavitel'a laickej kultúry, alebo jeho vzt’ah k náboženstvám, k fenoménu zjednocovania (unifikácie) práva? Prof. Janická ešte doplnila inú dimenziu už vykonaného a stále prebiehajúceho výskumu sasko-magdeburského práva a jeho prezentácie v právnej ikonografii a archeológii. Dr. Skřejpková z Univerzity Karlovej v Prahe následne ešte podčiarkla jeho vklad nielen do európskej právnej kultúry, ale, nepochybne, i do svetovej. Prítomná vedecká obec sa tak iste zjednotila na záverečnom názore, vnímanom aj ako expozé budúcich výskumov, že sasko-magdeburské právo nemožno chápat' monoliticky, ale naopak i ono malo rôzne svoje invarianty, ktoré boli ovplyvnené najmä domácim (lokálnym) vývojom, takým jedinečným ako sama Európa. V konferencii a v doterajšom výskume tol'ko pertraktovaný a tematizovaný z rôznych uhlov pohl'adu právny či iný duchovný transfer mal 
svojich otvorených príjemcov aj brániacich sa odporcov. Zostáva verit', že uvedená stále aktuálna „saská téma“ zostane v centre a nie na periférii vedeckého bádania súčasných humanitných a spoločenských vedcov strednej a východnej Európy.

doi: $10.14712 / 2464689 X .2019 .26$

Adriana Švecová 